\title{
RESEARCH
}

Open Access

\section{Palm oil extracts protected against cadmium chloride poisoning via inhibition of oxidative stress in rats}

Patrick Chukwuyenum Ichipi-Ifukor ${ }^{*}$ (10, Samuel Ogheneovo Asagba', Chibueze Nwose', Joseph Chukwufumnanya Mordi² and John Chukwuma Oyem ${ }^{3,4}$

\begin{abstract}
Background: The probable mechanism of an earlier reported capacity of palm oil extracts to confer protection against high dose cadmium poisoning in rats was reported in this study. Similar experimental design earlier reported by us was retained. Rats therefore were sacrificed at intervals of twelve; twenty four and forty eight hours post $\mathrm{CdCl}_{2}$ insult.
\end{abstract}

Results: Oxidative stress and antioxidant status (malondialdehyde, superoxide dismutase, catalase and glutathione) were assessed in tissues (liver, kidney, heart, brain, muscle) and serum. Oxidative stress indicators showed a significantly $(p<0.05)$ increased lipid peroxidation and alterations in antioxidant defence systems occasioned by drop in catalase and superoxide dismutase enzymes (serum, liver, heart, brain and kidneys) of the rats. Also observed were significant $(p<0.05)$ reduction in the non-enzymatic antioxidant reduced glutathione over time. Pre-administration of rats with the crude palm oil and its extracts modulated cadmium mediated depletion of the antioxidant capacities of rats acutely exposed to cadmium and rising lipid peroxidation profile.

Conclusions: Regulation of stress and antioxidant response was the underlying mechanism by which the extracts conferred protection against high dose cadmium insult thus suggesting its potential as a viable therapeutic target against its deleterious effects.

Keywords: Cadmium chloride, Pre-treatment, Oxidative stress, Antioxidants, Palm oil

\footnotetext{
*Correspondence: pcichipi-ifukor@delsu.edu.ng

1 Department of Biochemistry, Faculty of Science, Delta State University,

Abraka, Nigeria

Full list of author information is available at the end of the article
}

\section{Springer Open}

(c) The Author(s) 2021. Open Access This article is licensed under a Creative Commons Attribution 4.0 International License, which permits use, sharing, adaptation, distribution and reproduction in any medium or format, as long as you give appropriate credit to the original author(s) and the source, provide a link to the Creative Commons licence, and indicate if changes were made. The images or other third party material in this article are included in the article's Creative Commons licence, unless indicated otherwise in a credit line to the material. If material is not included in the article's Creative Commons licence and your intended use is not permitted by statutory regulation or exceeds the permitted use, you will need to obtain permission directly from the copyright holder. To view a copy of this licence, visit http://creativecommons.org/licenses/by/4.0/. 


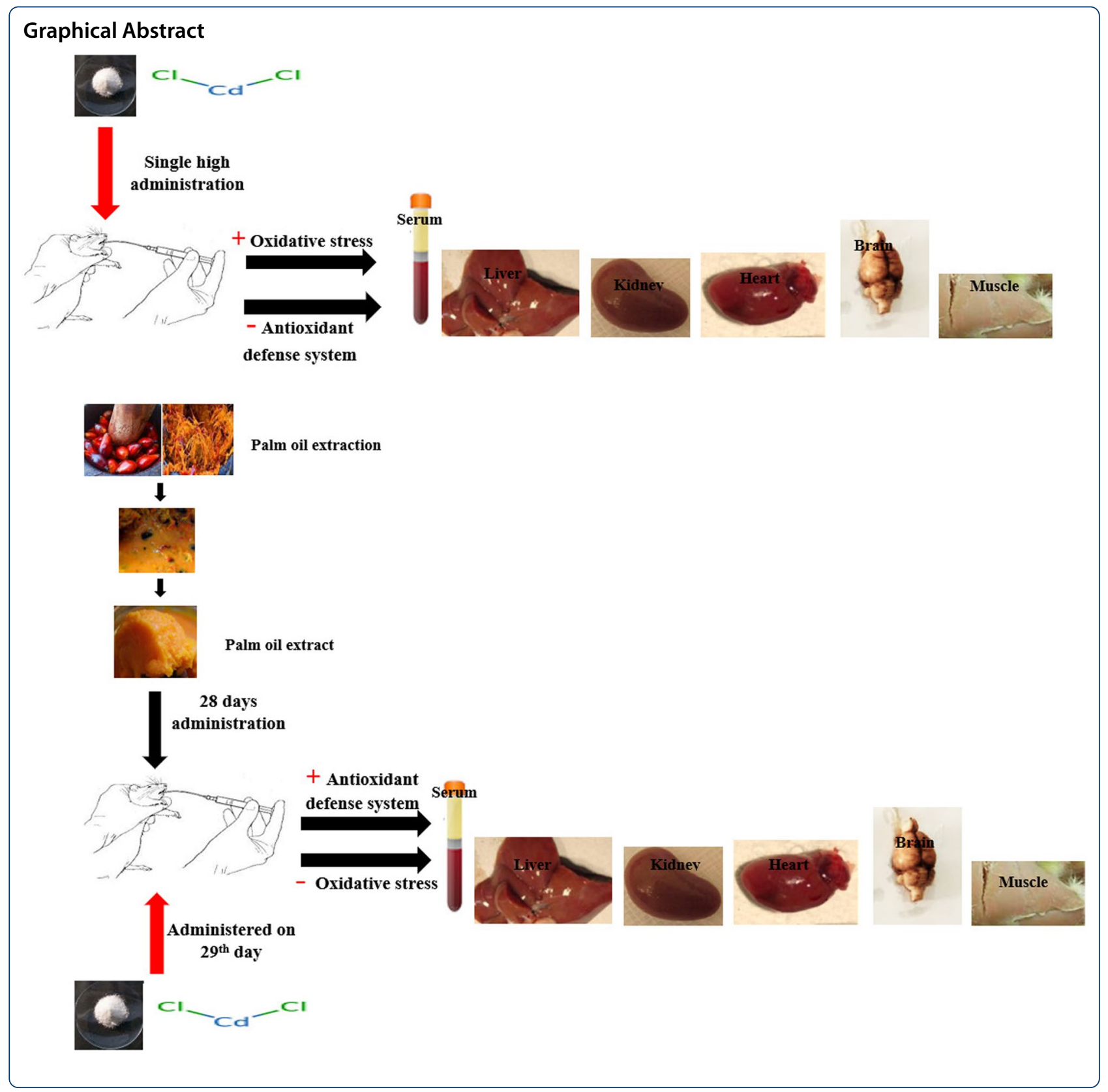

\section{Highlights}

1. 28 days administration of Palm oil and its fractions contributed in boosting antioxidant defence system by increasing activities of superoxide dismutase (SOD), Catalase (CAT) and levels of reduced glutathione (GSH) in serum rat tissues.

2. Administration of cadmium chloride led to increased peroxidation of lipid marked by high levels of malondialdehyde (MDA) within $48 \mathrm{~h}$.
3. The boosted antioxidant capacity responded in sequestration of increasing oxidative radicals within the system to restore stability.

4. Oxidative radicals contributes to inhibition and depletion of antioxidants (CAT, SOD and GSH).

\section{Background}

Cadmium poses risk at the slightest level of exposure to animals and plants. This is because the body does not have much capacity to degrade it to less harmful chemical 
forms. It is poorly excreted and is easily bio-accumulated (Dong et al. 2019). When exposed to the body, several organs and tissues are under attack. Cadmium endangers immune and metabolic stability. In acute cadmium poisoning, its symptoms usually manifests within $24 \mathrm{~h}$ affecting cardiovascular functions. This leads to shortness of breath, general weakness and fever. In some other severe cases, it may manifest in form of pneumonia, respiratory malfunctioning and death (Massanyi et al. 2020). The management of heavy metal poisoning like lead and cadmium basically relies on use of chelating agents which in most cases are expensive with significant side effects (Twumasi et al. 2014). The use of natural products for treatments of various forms of poisoning proves to exert negligible side effects and is not financially debilitating (Oyem et al. 2021; Orororo et al. 2018a, b, c, d, e; Okpoghono et al. 2018; Atagana and Asagba 2015).

Palm oil emanates from the fleshy mesocarp of the African oil palm tree (Elaeis guineensis Jacquin) (Mahlia et al. 2019). It belongs to the Palmae family and has the ability of growing up to a height of $20-30 \mathrm{~m}$ as well as having an economic life span between 20 and 30 years. The extraction of palm oil is done either mechanically or through traditional methods of milling of the fleshy mesocarp of the oil palm fruit (Edem and Akpanabiatu 2006; Lara Alvarenga et al. 2019). The oil is rich in carotenoids which gives its characteristically orange red colour and also has phospholipids, vitamin $\mathrm{E}$ and other essentials as constituents (Obahiagbon 2012).

Aside being a major constituent of food and the major source of carotenoids, the key dietetic and vigor promoting constituent of palm oil is fatty acids (Lara Alvarenga et al. 2019; Gutbrod et al. 2021). These constituents of palm oil are the basis for beneficial property of this man's food source which has been increasingly used as antidote for accidental consumption of noxious substances. In the light of this a record of its ethnopharmacological importance abounds in literature. For example, its antimicrobial efficacy was reported and well documented by Ekwenye and Ijeomah (2005), it is applied in traditional medicine as a treatment for several diseases and skin infections in South Eastern Nigeria and other parts of the world (Abbasi et al. 2010). Palm oil (Elaeis guineensis Jacquin) is reported to have antidotal, aphrodisiac and a diuretic efficacy while folklore medicine sees it as a remedy for headaches, pains, rheumatism, thrombosis and cardiac diseases (Ekwenye and Ijeomah 2005; Sasidharan et al. 2012; Ismail et al. 2018).

As a remedy for chemical and other variety of poisons, Nguefack et al. (2017) reports that it is used by local inhabitants of Yaounde, Cameroun as a quick antidote before clinical presentation. While together with other herbs, its administration is said to act as antidotes for several poisonous agents including chemicals in South East and South Western Nigeria (Owoyele and Owolabi 2014). Its efficacy has been reported for the treatment of Cyanide poisoning due to consumption of poorly processed cassava (Manihotesculanta Crantz) (Ononogbu 1990; Uvere 1999). Crude palm oil and its fractions have been experimentally tried as a natural remedy against lead poisoning (Twumasi et al. 2014). While it has been comparatively explored as a natural attenuator of lead and cadmium accumulation in the liver of Wistar rats (Nwaokocha et al. 2012), it has also been explored for management of diet mediated crude oil poisoning (Achuba and Ogwumu 2014; Achuba 2018).

This report is a continuation of our ongoing study, which reported the beneficial effects of palm oil fraction pre-treatment. The current paper therefore postulates that a systematic control of oxidative stress status is a dependent biochemical and metabolic adjustment by which palm oil fraction pre-treatment conferred protection against the deleterious effects and enzymatic destabilizing responses arising from high dose exposure to cadmium over a $48 \mathrm{~h}$ period.

\section{Methods}

\section{Drugs and chemicals used}

Cadmium salt $\left(\mathrm{CdCl}_{2}\right)$ used in this study was purchased from Sigma Aldrich Co. Poole England. Other analytical grade chemicals were also purchased from Sigma Aldrich Co and British Drug House Chemicals, Poole, England.

\section{Palm fruit collection, extraction and fractionation of palm oil}

Palm fruit collection and identification, extraction, fractionation and procedures for preliminary antioxidant constituent analysis was carried out as previously reported by Ichipi-Ifukor et al (2019a).

\section{Ethical approval}

Approval for the current study was given by the Faculty of Science Ethics committee and it has an approved study number ETH/15/16/PG223056. The ethics for the study also conformed to the guidelines for animal research stated by the Animal Research Ethics (2009) and the World Medical Association (2016) on use of animal for research.

\section{Animal mobilization and experimental design}

The study utilized 72 male rats that were purchased from the Emma Maria Research Laboratory and Consultancy Abraka, Nigeria. They had an average weight range of 180-200 g, were also between 8 and 10 weeks old. Following a two weeks period of acclimation to the study environment, they were shared into six groups (1-6) made 
up of 12 animals per group. All animals were allowed to access water and commercial rat chow at will, a cycle of $12 \mathrm{~h}$ light and $12 \mathrm{~h}$ darkness throughout the study period. Pre-treatment with $5 \mathrm{ml} / \mathrm{Kg}$ body weight of the palm oil fractions: groups 3-6 (Crude fraction: CF, Gel fraction: GF, Bleached fraction: BF and Unsaponifiable fraction UF), followed a timeframe of 28 days after putting into consideration the lethal dose of an undiluted palm oil $5 \mathrm{~g} / \mathrm{kg}$ body weight as reported by Johnson and Slag (2009). This was eventually followed by a single high dose (20 mg/kg bodyweight) administration of cadmium chloride $\left(\mathrm{CdCl}_{2}\right)$ based on an earlier established lethal dose of cadmium chloride at $88 \mathrm{mg} / \mathrm{kg}$ body weight and its toxicity potential put at $15.3 \mathrm{mg} / \mathrm{kg}$ body weight within $24 \mathrm{~h}$ (Agency for Toxic Substances and Disease Registry (ATSDR) 2008) for groups 2-6. All administration was done by gavage using a $5 \mathrm{ml}$ syringe and four rats from each group were sacrificed at intervals of twelve hours, twenty four hours and forty eight hours after cadmium chloride administration.

\section{Collection and preparation of samples}

Rats were sacrificed via cervical decapitation at different time intervals of twelve hours, twenty four hours, and forty eight hours respectively after administration of cadmium chloride. The blood and tissue samples were collected after cervical dislocation of the rats were carried out. Blood samples collection was done after cutting the rats open through cardiac puncture. Organs such as liver, kidney and heart were harvested, weighed and kept in well labelled containers. Whole brain was collected by carefully cutting open the skull while the muscle tissue was collected from the lower right leg around the femoral region. Preparation of the serum and tissue homogenates for analysis was maintained under a cold chain as earlier reported (Ichipi-Ifukor et al. 2019b).

\section{Analysis of oxidative stress indices}

Oxidative stress and antioxidant indices were analysed by standard procedures. Lipid peroxidation noted by Malondialdehyde (MDA) concentrations was carried out by the method of Gutteridge and Wilkins (1982); the reduced glutathione (GSH) was estimated in serum and tissue homogenates using the method of Ellman (1959) while the activity of superoxide dismutase (SOD) in the serum and tissue homogenates was estimated spectrophotometrically using an earlier published method of Misra and Fredorich (1972). Catalase (CAT) activity assay was carried out by the method of Cohen et al. (1972).

\section{Method of statistical analysis}

Data was analysed using the computer software the statistical package for social sciences version 21 (SPSS 21).
The simple analysis of variance (ANOVA) was used, while multiple comparisons of the means across groups were done using Tukey HSD analysis at a significant level of $p<0.05$.

\section{Result}

Palm oil fractions abates rise in malondialehyde (MDA)

The result presented in Table 1 shows the levels of Malondialdehyde (MDA) in tissue and serum after $12 \mathrm{~h}, 24 \mathrm{~h}$ and $48 \mathrm{~h}$ of acute cadmium post-administration periods in rats pre-treated with palm oil and palm oil extracts. There were elevated levels of MDA in only cadmium administered rats in all tissues $12 \mathrm{~h}, 24 \mathrm{~h}$ and $48 \mathrm{~h}$ post cadmium administration periods except in the brain $(12 \mathrm{~h}$ and $24 \mathrm{~h})(p<0.05)$. At the end of the $48 \mathrm{~h}$ treatment periods, pre-treatment with palm oil and its extracts mediated the reduction in MDA levels in all tissues except for CF and UF relative to control group 2 . Put together the findings of this study suggests that GF and UF conferred more protection against rise in stress indices.

\section{Palm oil fractions mitigates depletion of reduced glutathione}

The result presented in Table 2 shows the levels of reduced glutathione in tissue and serum after $12 \mathrm{~h}, 24 \mathrm{~h}$ and $48 \mathrm{~h}$ of acute cadmium administration in rats pretreated with palm oil and palm oil fractions. At the end of $12 \mathrm{~h}$ period, GSH reduced in (liver, kidney and heart) of all groups administered cadmium chloride (2-6) while (Brain, muscle and serum) remained significantly unchanged.

Reduction in GSH levels in cadmium only groups continued in all other tissues and serum except muscle $24 \mathrm{~h}$ and $48 \mathrm{~h}$ post administration periods relative to control. Pre-treatment with palm oil fractions increased GSH levels near control levels (except for CF in liver, brain after $24 \mathrm{~h}$ ) and liver, heart, and all groups in the brain after $48 \mathrm{~h}$ cadmium intoxication which had no significance compared to cadmium only groups. Changes in GSH depletion relative to control indicate a negative change potential in all tissues except for UF kidney and CF brain $12 \mathrm{~h}$ post cadmium treatment. The liver in all treatment periods had the highest level of GSH. On the whole, the GF and CF offered more protection against the depletion of GSH in rats.

\section{Palm oil fractions inhibits reduction of catalse enzyme activities}

The result presented in Table 3 shows the activity of catalase in tissues and serum after $12 \mathrm{~h}, 24 \mathrm{~h}$ and $48 \mathrm{~h}$ of acute cadmium administration in rats pre-treated with CF and its fractions. 
Table 1 Effect of palm oil fractions on levels of malondialdehyde (MDA) in tissue and serum of rats administered cadmium $\left(\mu \mathrm{mol} \mathrm{ml^{-1 } )}\right.$

\begin{tabular}{|c|c|c|c|c|c|c|}
\hline \multirow[t]{2}{*}{ Tissues } & \multicolumn{6}{|c|}{ Experimental groups } \\
\hline & 1 & 2 & 3 & 4 & 5 & 6 \\
\hline \multicolumn{7}{|c|}{ Twelve hours } \\
\hline Liver & $0.59 \pm 0.03^{\mathrm{a}}$ & $1.33 \pm 0.12^{b}$ & $1.21 \pm 0.18^{\mathrm{bd}}$ & $0.87 \pm 0.02^{c}$ & $1.24 \pm 0.04^{\mathrm{bd}}$ & $1.08 \pm 0.10^{\mathrm{cd}}$ \\
\hline Kidney & $0.70 \pm 0.08^{\mathrm{a}}$ & $1.27 \pm 0.02^{b}$ & $0.94 \pm 0.19^{a b}$ & $0.89 \pm 0.12^{\mathrm{a}}$ & $0.95 \pm 0.22^{\mathrm{ab}}$ & $0.96 \pm 0.14^{\mathrm{ab}}$ \\
\hline Heart & $0.54 \pm 0.27^{\mathrm{a}}$ & $1.34 \pm 0.22^{b}$ & $1.12 \pm 0.08^{b}$ & $0.77 \pm 0.11^{\mathrm{a}}$ & $1.04 \pm 0.04^{b}$ & $1.14 \pm 0.09^{b}$ \\
\hline Brain & $0.44 \pm 0.15$ & $0.48 \pm 0.10$ & $0.51 \pm 0.11$ & $0.47 \pm 0.08$ & $0.51 \pm 0.19$ & $0.39 \pm 0.24$ \\
\hline Muscle & $0.63 \pm 0.06^{\mathrm{a}}$ & $0.83 \pm 0.12^{\mathrm{ab}}$ & $0.81 \pm 0.15^{\mathrm{ab}}$ & $0.84 \pm 0.09^{\mathrm{ab}}$ & $0.78 \pm 0.08^{\mathrm{ab}}$ & $0.87 \pm 0.07^{b}$ \\
\hline Serum & $0.56 \pm 0.05^{\mathrm{a}}$ & $0.92 \pm 0.05^{b}$ & $0.73 \pm 0.11^{c}$ & $0.82 \pm 0.06^{b}$ & $0.71 \pm 0.03^{c}$ & $0.82 \pm 0.06^{b}$ \\
\hline \multicolumn{7}{|c|}{ Twenty four hours } \\
\hline Liver & $0.85 \pm 0.09^{\mathrm{a}}$ & $2.72 \pm 0.15^{b}$ & $1.55 \pm 0.17^{c}$ & $1.40 \pm 0.39^{c}$ & $1.76 \pm 0.13^{c}$ & $1.12 \pm 0.06^{\mathrm{ac}}$ \\
\hline Kidney & $0.82 \pm 0.11^{\mathrm{a}}$ & $2.85 \pm 0.11^{b}$ & $1.17 \pm 0.32^{\mathrm{a}}$ & $1.08 \pm 0.20^{\mathrm{a}}$ & $1.00 \pm 0.13^{\mathrm{a}}$ & $1.04 \pm 0.16^{\mathrm{a}}$ \\
\hline Heart & $0.54 \pm 0.13^{\mathrm{a}}$ & $2.71 \pm 0.22^{b}$ & $1.40 \pm 0.16^{c}$ & $1.41 \pm 0.18^{c}$ & $1.50 \pm 0.16^{c}$ & $1.66 \pm 0.09^{c}$ \\
\hline Brain & $0.49 \pm 0.07$ & $0.58 \pm 0.19$ & $0.64 \pm 0.14$ & $0.69 \pm 1.00$ & $0.46 \pm 0.23$ & $0.46 \pm 0.29$ \\
\hline Muscle & $0.49 \pm 0.05^{\mathrm{a}}$ & $0.71 \pm 0.12^{\mathrm{ab}}$ & $0.68 \pm 0.09^{a b}$ & $0.82 \pm 0.08^{b}$ & $0.53 \pm 0.09^{\mathrm{a}}$ & $0.61 \pm 0.06^{b c}$ \\
\hline Serum & $0.63 \pm 0.10^{\mathrm{a}}$ & $1.52 \pm 0.84^{b}$ & $0.83 \pm 0.25^{a c}$ & $0.76 \pm 0.04^{\mathrm{ac}}$ & $0.99 \pm 0.07^{c}$ & $0.86 \pm 0.17^{a c}$ \\
\hline \multicolumn{7}{|c|}{ Forty eight hours } \\
\hline Liver & $0.70 \pm 1.07^{\mathrm{a}}$ & $2.87 \pm 0.16^{b}$ & $1.69 \pm 0.81^{c}$ & $1.34 \pm 0.18^{d}$ & $1.91 \pm 0.11^{c}$ & $1.69 \pm 0.08^{c}$ \\
\hline Kidney & $0.72 \pm 0.08^{\mathrm{a}}$ & $2.80 \pm 0.11^{b}$ & $1.45 \pm 0.17^{c}$ & $1.35 \pm 0.22^{c}$ & $1.76 \pm 0.06^{d}$ & $1.18 \pm 0.67^{c}$ \\
\hline Heart & $0.54 \pm 0.06^{\mathrm{a}}$ & $2.67 \pm 0.17^{b}$ & $1.46 \pm 0.16^{c}$ & $1.51 \pm 0.09^{c}$ & $1.46 \pm 0.09^{c}$ & $1.70 \pm 0.14^{c}$ \\
\hline Brain & $0.43 \pm 0.03^{\mathrm{a}}$ & $0.93 \pm 0.08^{b}$ & $0.66 \pm 0.03^{c}$ & $0.75 \pm 0.08^{c}$ & $0.53 \pm 0.08^{c}$ & $0.63 \pm 0.07^{c}$ \\
\hline Muscle & $0.51 \pm 0.05^{\mathrm{a}}$ & $0.83 \pm 0.05^{b}$ & $0.73 \pm 0.07^{b}$ & $0.79 \pm 0.06^{b}$ & $0.51 \pm 0.05^{\mathrm{a}}$ & $0.55 \pm 0.07^{a}$ \\
\hline Serum & $0.64 \pm 0.06^{\mathrm{a}}$ & $1.57 \pm 0.06^{b}$ & $0.78 \pm 0.07^{\mathrm{a}}$ & $0.88 \pm 0.07^{\mathrm{ad}}$ & $0.99 \pm 0.09^{c}$ & $0.96 \pm 0.07^{c d}$ \\
\hline
\end{tabular}

All values are expressed as Mean $\pm \mathrm{SD}$, values sharing different alphabet superscript on the same row showed a significant difference Key: $1=$ Control, $2=\mathrm{CdCl}_{2}, 3=\mathrm{CF}+\mathrm{CdCl}_{2}, 4=\mathrm{GF}+\mathrm{CdCl}_{2}, 5=\mathrm{BF}+\mathrm{CdCl}_{2,}, 6=\mathrm{UF}+\mathrm{CdCl}_{2}$

The activity of catalase in the organs (liver, kidney and heart) of cadmium treated (group B) showed a significant $(p<0.05)$ reduction after $12 \mathrm{~h}, 24 \mathrm{~h}$ and $48 \mathrm{~h}$ periods of exposure compared to control (group $1)$. Conversely, activity of the enzyme was significantly $(p<0.05)$ increased in the (liver, kidney, heart and serum) of all pre-treated groups relative to group 2 but reduced compared to group 1 after $12 \mathrm{~h}$. Similar trends were observed in all tissues and serums after $24 \mathrm{~h}$ period except for muscle tissue which was not significant $(p>0.05)$ compared to cadmium only group.

At the end of $48 \mathrm{~h}$ treatment period, similar trends of significant $(p<0.05)$ increase in all tissues except for brain in palm oil and its fraction pre-treated groups were observed relative to cadmium only groups while reductions occurred relative to control. It also showed a gradual up regulation of the enzyme activities as conferred by palm oil fractions pre-treatment with $\mathrm{CF}$ conferring a greater level of protection.

\section{Palm oil fractions inhibits superoxide dismutase enzyme activities in ratsAfter $\mathrm{CdCl}_{2}$ exposure}

The results presented in Table 4 shows the activity of Superoxide Dismutase (SOD) in tissues and serum after $12 \mathrm{~h}, 24 \mathrm{~h}$ and $48 \mathrm{~h}$ of acute cadmium administration in rats pre-treated with palm oil and palm oil extracts. Irrespective of the duration of exposure, the SOD activity was significantly decreased in the serum and tissues (brain and muscle excluded) of $\mathrm{Cd}$ exposed rats (group 2) as compared to control (group 1). No significant $(p>0.05)$ effect on SOD activity was observed in the brain in all periods of exposure to Cd. Similarly, no significant change was observed in Muscle SOD activity after $12 \mathrm{~h}$ exposure to $\mathrm{Cd}$. Irrespective of duration, pretreatment of $\mathrm{Cd}$ exposed rats with palm oil and palm oil extracts (groups 3-6) significantly increased (brain excluded) the serum and tissue SOD activity relative to rats exposed to $\mathrm{Cd}$ alone (group 2). 
Table 2 Effect of palm oil fractions on levels of reduced glutathione (GSH) in tissues and serum of rats administered cadmium ( $\mu$ mol/ mg protein)

\begin{tabular}{|c|c|c|c|c|c|c|}
\hline \multirow[t]{2}{*}{ Tissues } & \multicolumn{6}{|c|}{ Experimental groups } \\
\hline & 1 & 2 & 3 & 4 & 5 & 6 \\
\hline \multicolumn{7}{|c|}{ Twelve hours } \\
\hline Liver & $22.25 \pm 3.52^{\mathrm{a}}$ & $12.75 \pm 2.22^{b}$ & $14.00 \pm 1.83^{b}$ & $16.50 \pm 2.08^{b}$ & $15.05 \pm 2.25^{b}$ & $14.25 \pm 3.86^{b}$ \\
\hline Kidney & $16.32 \pm 1.83^{\mathrm{a}}$ & $11.85 \pm 2.55^{b}$ & $12.69 \pm 2.40^{\mathrm{b}}$ & $14.67 \pm 1.30^{\mathrm{b}}$ & $11.79 \pm 1.80^{\mathrm{b}}$ & $11.72 \pm 1.4^{\mathrm{b}}$ \\
\hline Heart & $8.29 \pm 0.82^{\mathrm{a}}$ & $4.61 \pm 0.39^{b}$ & $6.36 \pm 1.49^{\mathrm{ab}}$ & $5.99 \pm 1.23^{\mathrm{ab}}$ & $5.12 \pm 0.91^{\mathrm{ab}}$ & $8.15 \pm 1.52^{\mathrm{a}}$ \\
\hline Brain & $1.96 \pm 0.46$ & $2.12 \pm 0.39$ & $1.74 \pm 0.54$ & $1.27 \pm 0.19$ & $1.69 \pm 0.52$ & $1.22 \pm 0.39$ \\
\hline Muscle & $2.48 \pm 0.22$ & $2.04 \pm 0.39$ & $2.10 \pm 0.32$ & $1.80 \pm 0.59$ & $2.10 \pm 0.199$ & $2.10 \pm 0.21$ \\
\hline Serum & $10.22 \pm 1.86$ & $8.00 \pm 1.42$ & $10.64 \pm 1.54$ & $9.94 \pm 2.95$ & $9.53 \pm 1.47$ & $9.39 \pm 1.41$ \\
\hline \multicolumn{7}{|c|}{ Twenty four hours } \\
\hline Liver & $21.10 \pm 2.58^{\mathrm{a}}$ & $7.75 \pm 1.71^{b}$ & $11.23 \pm 2.45^{b c}$ & $15.75 \pm 0.96^{c}$ & $12.71 \pm 2.14^{c}$ & $13.88 \pm 2.58^{c}$ \\
\hline Kidney & $13.76 \pm 1.26^{\mathrm{a}}$ & $5.78 \pm 0.73^{b}$ & $10.95 \pm 1.62^{\mathrm{ac}}$ & $12.88 \pm 0.90^{\mathrm{ac}}$ & $10.45 \pm 1.49^{c}$ & $10.75 \pm 1.75^{c}$ \\
\hline Heart & $7.55 \pm 0.97^{\mathrm{a}}$ & $4.30 \pm 0.48^{b}$ & $5.50 \pm 1.17^{\mathrm{a}}$ & $5.84 \pm 0.87^{\mathrm{a}}$ & $5.17 \pm 0.92^{\mathrm{a}}$ & $6.68 \pm 1.07^{\mathrm{a}}$ \\
\hline Brain & $2.80 \pm 0.75^{\mathrm{a}}$ & $2.02 \pm 0.31^{b}$ & $1.82 \pm 0.35^{b c}$ & $1.36 \pm 0.15^{c}$ & $1.66 \pm 0.32^{b c}$ & $1.12 \pm 0.29^{c}$ \\
\hline Muscle & $2.43 \pm 0.24$ & $1.94 \pm 0.48$ & $1.99 \pm 0.38$ & $1.83 \pm 0.43$ & $1.99 \pm 0.25$ & $1.99 \pm 0.24$ \\
\hline Serum & $10.05 \pm 1.57^{\mathrm{a}}$ & $5.02 \pm 0.91^{b}$ & $9.35 \pm 1.42^{\mathrm{a}}$ & $8.40 \pm 2.09^{\mathrm{ac}}$ & $8.08 \pm 1.58^{b c}$ & $7.25 \pm 1.32^{c}$ \\
\hline \multicolumn{7}{|c|}{ Forty eight hours } \\
\hline Liver & $20.00 \pm 1.63^{\mathrm{a}}$ & $7.00 \pm 1.64^{b}$ & $9.70 \pm 1.83^{b}$ & $14.50 \pm 2.08^{c}$ & $11.21 \pm 2.65^{b c}$ & $11.50 \pm 1.91^{c}$ \\
\hline Kidney & $11.96 \pm 1.67^{\mathrm{a}}$ & $5.48 \pm 0.97^{b}$ & $9.50 \pm 1.04^{\mathrm{ac}}$ & $11.38 \pm 1.41^{\mathrm{a}}$ & $8.95 \pm 0.87^{c}$ & $9.70 \pm 0.93^{\mathrm{ac}}$ \\
\hline Heart & $7.30 \pm 1.20^{\mathrm{a}}$ & $4.15 \pm 0.60^{b}$ & $5.03 \pm 0.76^{b}$ & $5.37 \pm 0.45^{\mathrm{ab}}$ & $4.70 \pm 0.95^{b}$ & $5.95 \pm 1.32^{\mathrm{ab}}$ \\
\hline Brain & $2.71 \pm 0.77^{\mathrm{a}}$ & $1.80 \pm 0.16^{b}$ & $1.70 \pm 0.26^{\mathrm{b}}$ & $1.29 \pm 0.11^{\mathrm{b}}$ & $1.50 \pm 0.12^{b}$ & $1.26 \pm 0.43^{b}$ \\
\hline Muscle & $2.27 \pm 0.28$ & $1.81 \pm 0.35$ & $1.79 \pm 0.17$ & $1.70 \pm 0.48$ & $1.87 \pm 0.15$ & $1.85 \pm 0.19$ \\
\hline Serum & $9.35 \pm 1.07^{\mathrm{a}}$ & $4.90 \pm 0.96^{b}$ & $8.35 \pm 0.53^{\mathrm{a}}$ & $7.43 \pm 1.16^{\mathrm{a}}$ & $7.38 \pm 0.97^{\mathrm{a}}$ & $6.63 \pm 0.96^{\mathrm{ab}}$ \\
\hline
\end{tabular}

All values are expressed as Mean $\pm S D$, values sharing different alphabet superscript on the same row showed a significant difference.

Key: $1=$ Control, $2=\mathrm{CdCl}_{2} 3=\mathrm{CF}+\mathrm{CdCl}_{2,} 4=\mathrm{GF}+\mathrm{CdCl}_{2}, 5=\mathrm{BF}+\mathrm{CdCl}_{2,} 6=\mathrm{UF}+\mathrm{CdCl}_{2}$

In all groups pre-treated with $\mathrm{CF}, \mathrm{GF}, \mathrm{BF}$ and $\mathrm{UF}$, there were observed significant increase in SOD activities relative to cadmium only group in (Liver, Kidney, Heart, Muscle and Serum) after $24 \mathrm{~h}$ and $48 \mathrm{~h}$ periods but significantly reduced relative to control for CF (Muscle and liver excluded), GF (Muscle and heart excluded), BF (liver and Muscle excluded) and UF (liver and kidney excluded) after twenty four hours of treatment. Findings further reveals that $\mathrm{CF}$ and $\mathrm{GF}$ were more effective in reversing the effect of $\mathrm{CdCl}_{2}$ on SOD activity.

\section{Discussion}

Here we show a persistent rise in oxidation of lipids noted by high degree of (MDA) in the organs (Liver, Kidney and Heart) and serum (Table 1) of rats exposed to cadmium chloride only. This is consistent with available information in literature which noted that onset of rise in peroxidation of lipids within tissues occurs in response to overwhelming rise in reactive oxygen and nitrogen species (ROS and RNS). This alarming increase is often influenced by uncontrolled depletion of antioxidants serving as scavengers for ROS and RNS (Ramalingam and Kim 2012; Oyem et al. 2021).
Although the onset of increase in MDA was higher in the liver and was time dependent, there was significant rise in all tissues and serum except for the brain and muscle tissues. It is notable to say that modulation of rise in MDA levels occurred first in the kidney of rats administered the GF when compared to rats receiving only cadmium as significant reductions were first observed at the 12 hour post administration period followed by a nonsignificant increase in all other tissues and serum. Likewise, reductions in MDA concentrations in the liver of $\mathrm{CdCl}_{2}$ administered rats pre-treated with gel fraction $12 \mathrm{~h}$ post $\mathrm{CdCl}_{2}$ administration. At the end of the 24 and 48 hours mark, significant reductions in liver lipid peroxidation comparative to the cadmium only (Group 2) were also reported in rats pre-treated with crude fraction, gel fraction, bleached fraction and unsaponifiable fractions. Thus the modulation of liver lipid peroxidation was significant at the end of 24 and 48 hours relative to group $2\left(\mathrm{CdCl}_{2}\right.$ only) unlike the kidney were a non-significant increase was very evident due to its reduction to near normality relative to the control by the crude fraction, gel fraction, bleached fraction and unsaponifiable fraction. This trend is in line with our earlier published data 
Table 3 Effect of palm oil fractions on activities of tissue and serum catalase (CAT) of rats administered cadmium ( $\mu \mathrm{mol} \mathrm{min}^{-1} \mathrm{~g}^{-1}$ tissue)

\begin{tabular}{|c|c|c|c|c|c|c|}
\hline \multirow[t]{2}{*}{ Tissues } & \multicolumn{6}{|c|}{ Experimental groups } \\
\hline & 1 & 2 & 3 & 4 & 5 & 6 \\
\hline \multicolumn{7}{|c|}{ Twelve hours } \\
\hline Liver & $49.41 \pm 5.91^{\mathrm{a}}$ & $26.03 \pm 1.66^{b}$ & $42.52 \pm 5.99^{\mathrm{a}}$ & $41.91 \pm 2.59^{\mathrm{a}}$ & $39.24 \pm 5.65^{c}$ & $27.28 \pm 2.35^{b}$ \\
\hline Kidney & $36.33 \pm 3.48^{\mathrm{a}}$ & $22.79 \pm 1.20^{b}$ & $30.88 \pm 2.73^{\mathrm{a}}$ & $28.72 \pm 2.50^{b}$ & $33.82 \pm 3.91^{\mathrm{a}}$ & $24.96 \pm 3.61^{b}$ \\
\hline Heart & $37.85 \pm 2.15^{\mathrm{a}}$ & $25.16 \pm 2.57^{b}$ & $29.84 \pm 1.87^{b}$ & $39.77 \pm 7.83^{\mathrm{a}}$ & $37.78 \pm 2.01^{\mathrm{a}}$ & $24.73 \pm 2.94^{b}$ \\
\hline Brain & $44.34 \pm 4.67^{\mathrm{a}}$ & $39.87 \pm 3.67^{\mathrm{ab}}$ & $40.42 \pm 5.76^{\mathrm{ab}}$ & $36.78 \pm 4.87^{b}$ & $38.94 \pm 4.76^{\mathrm{ab}}$ & $36.74 \pm 2.88^{b}$ \\
\hline Muscle & $43.18 \pm 2.61^{a}$ & $34.55 \pm 4.15^{\mathrm{a}}$ & $39.55 \pm 5.82^{a}$ & $37.29 \pm 5.17^{\mathrm{a}}$ & $40.64 \pm 2.97^{\mathrm{a}}$ & $43.74 \pm 3.39^{\mathrm{a}}$ \\
\hline Serum & $41.47 \pm 7.31^{\mathrm{a}}$ & $25.01 \pm 3.29^{b}$ & $32.28 \pm 2.38^{\mathrm{a}}$ & $32.64 \pm 3.29^{\mathrm{a}}$ & $39.09 \pm 2.24^{\mathrm{a}}$ & $35.49 \pm 4.82^{\mathrm{a}}$ \\
\hline \multicolumn{7}{|c|}{ Twenty four hours } \\
\hline Liver & $52.40 \pm 4.52^{\mathrm{a}}$ & $12.38 \pm 1.83^{b}$ & $40.51 \pm 3.52^{c}$ & $39.60 \pm 6.74^{c}$ & $29.94 \pm 1.83^{d}$ & $23.22 \pm 2.54^{d}$ \\
\hline Kidney & $36.29 \pm 2.78^{a}$ & $10.19 \pm 1.74^{b}$ & $33.65 \pm 2.59^{\mathrm{a}}$ & $31.81 \pm 5.71^{\mathrm{a}}$ & $24.95 \pm 3.61^{c}$ & $20.21 \pm 3.72^{c}$ \\
\hline Heart & $39.72 \pm 2.38^{\mathrm{a}}$ & $14.91 \pm 3.33^{b}$ & $31.71 \pm 2.62^{c}$ & $28.35 \pm 2.74^{c}$ & $27.49 \pm 2.48^{c}$ & $22.81 \pm 2.01^{d}$ \\
\hline Brain & $42.21 \pm 4.77^{a}$ & $38.08 \pm 1.79^{b}$ & $33.03 \pm 3.61^{c}$ & $31.32 \pm 2.76^{c}$ & $23.66 \pm 2.55^{b}$ & $22.38 \pm 1.83^{b}$ \\
\hline Muscle & $43.18 \pm 3.81^{\mathrm{a}}$ & $31.54 \pm 3.59^{b}$ & $38.15 \pm 5.90^{b}$ & $38.16 \pm 3.60^{b}$ & $35.35 \pm 518^{b}$ & $44.65 \pm 1.89^{\mathrm{a}}$ \\
\hline Serum & $42.21 \pm 4.78^{a}$ & $18.08 \pm 1.79^{b}$ & $33.03 \pm 3.61^{c}$ & $31.32 \pm 2.76^{c}$ & $22.66 \pm 2.55^{b}$ & $22.38 \pm 1.83^{b}$ \\
\hline \multicolumn{7}{|c|}{ Forty eight hours } \\
\hline Liver & $51.29 \pm 2.66^{\mathrm{a}}$ & $13.24 \pm 2.57^{b}$ & $40.90 \pm 4.77^{c}$ & $36.59 \pm 5.09^{\mathrm{cd}}$ & $30.21 \pm 2.33^{\text {de }}$ & $23.94 \pm 3.45^{\mathrm{e}}$ \\
\hline Kidney & $37.29 \pm 2.58^{a}$ & $10.50 \pm 1.30^{b}$ & $35.69 \pm 3.00^{\mathrm{a}}$ & $26.26 \pm 4.35^{c}$ & $30.80 \pm 6.08^{\mathrm{a}}$ & $21.66 \pm 3.54^{c}$ \\
\hline Heart & $47.33 \pm 3.43^{\mathrm{a}}$ & $17.72 \pm 2.33^{b}$ & $43.91 \pm 3.72^{\mathrm{a}}$ & $34.34 \pm 2.80^{c}$ & $40.78 \pm 5.88^{a}$ & $37.51 \pm 7.32^{\mathrm{ac}}$ \\
\hline Brain & $42.75 \pm 3.12^{\mathrm{a}}$ & $36.86 \pm 6.35^{\mathrm{a}}$ & $36.50 \pm 4.43^{\mathrm{a}}$ & $34.34 \pm 2.80^{\mathrm{a}}$ & $40.77 \pm 5.88^{a}$ & $37.51 \pm 7.32^{\mathrm{a}}$ \\
\hline Muscle & $43.32 \pm 3.31^{\mathrm{a}}$ & $33.74 \pm 4.52^{b}$ & $43.55 \pm 2.36^{a}$ & $36.73 \pm 3.37^{\mathrm{ab}}$ & $36.62 \pm 2.86^{\mathrm{ab}}$ & $39.02 \pm 2.40^{a b}$ \\
\hline Serum & $40.84 \pm 2.11^{\mathrm{a}}$ & $19.16 \pm 2.57^{b}$ & $32.14 \pm 4.34^{\mathrm{ac}}$ & $33.40 \pm 2.32^{c}$ & $31.13 \pm 5.17^{c}$ & $32.50 \pm 4.29^{a c}$ \\
\hline
\end{tabular}

All values are expressed as Mean $\pm S D$, values sharing different alphabet superscript on the same row showed a significant difference.

Key: $1=$ Control, $2=\mathrm{CdCl}_{2} 3=\mathrm{CF}+\mathrm{CdCl}_{2}, 4=\mathrm{GF}+\mathrm{CdCl}_{2}, 5=\mathrm{BF}+\mathrm{CdCl}_{2}, 6=\mathrm{UF}+\mathrm{CdCl}_{2}$

(Ichipi-Ifukor et al. 2019b) on the reduction of activities of oxidative enzymes (aldehyde oxidase and sulphite oxidase) at the end of twenty four and forty eight hours to near normality by pre-treatment with CF, GF, BF and UF in the livers and kidneys. This observation therefore further substantiates an earlier claim that oxidative enzymes rise, often occur as second messenger responders to generation of sulfoxides, $\mathrm{N}$-oxides and aldehydes arising from oxidation of lipids within the tissue architecture (Kweki et al. 2018; Asagba 2005; Isamah and Asagba 2004).

We have previously showed that crude fractions and gel fractions of palm oil possesses high levels of tocopherols and carotenoids (Ichipi-Ifukor et al. 2019a), which may be justification for the high potency in prevention of lipid peroxidation. These phytonutrients have also been severally implicated in the fortification of tissues due to rich availability of phospholipids which interacts with vitamin $\mathrm{E}$ and other antioxidant cascades for the sustenance of oxidative homeostasis (Obahaigbon 2012; Oguntibeju et al. 2012). This also is in line with the submissions of Twumasi et al. (2014) and Osei (2013) who noted the ability of these extracts to reverse to normal levels of haematological parameters, serum aspartate amino transferase (AST) and Alanine amino transferase (ALT) relative to control after the extracts have been used to treat rats poisoned with lead.

Likewise, the observations made in this study is in consonance with the submissions of Nwokocha et al. (2012) whose result revealed the benefit of palm oil diet supplementation to alter the induced oxidative erosion caused by lead and cadmium. They further submitted as in this study that the hepato-protective effect might be correlated with its antioxidant, free radical scavenger effects, hepatic drug-metabolizing enzymes induction and probably chelating properties. Earlier we also reported the ability of palm oil fractions pre-treatment to alter haematotoxicity owing to their ability to induce several levels of immune responses that mediates the protection of the tissue membranes from oxidative damage (Asagba et al. 2019). The insignificant efficacy of cadmium mediated rise in brain lipid disarmament may be justified by the reduced ability of the metal to cross the blood brain barrier thus preventing cadmium from causing very serious deleterious effects in the brain (Ichipi-Ifukor et al. 2013; Asagba and Obi 2005). 
Table 4 Effect of palm oil fractions on activities of tissue and serum superoxide dismutase (SOD) of rats administered $\mathrm{CdCl}_{2}$ (Units $\mathrm{g}^{-1}$ tissue) or (Units $\mathrm{ml}^{-1}$ ) in serum

\begin{tabular}{|c|c|c|c|c|c|c|}
\hline \multirow[t]{2}{*}{ Tissues } & \multicolumn{6}{|c|}{ Experimental groups } \\
\hline & 1 & 2 & 3 & 4 & 5 & 6 \\
\hline \multicolumn{7}{|c|}{ Twelve hours } \\
\hline Liver & $70.38 \pm 5.72^{a}$ & $25.36 \pm 2.63^{b}$ & $63.38 \pm 2.66^{\mathrm{ac}}$ & $69.39 \pm 4.36^{a}$ & $55.66 \pm 2.60^{\mathrm{ac}}$ & $63.56 \pm 2.66^{c}$ \\
\hline Kidney & $76.85 \pm 3.07^{\mathrm{ac}}$ & $39.15 \pm 5.30^{b}$ & $80.16 \pm 6.28^{a}$ & $76.19 \pm 4.08^{\mathrm{ac}}$ & $68.19 \pm 4.28^{c}$ & $67.36 \pm 5.36^{c}$ \\
\hline Heart & $69.0 .81 \pm 4.33^{a}$ & $50.41 \pm 5.37^{b}$ & $63.16 \pm 5.06^{\mathrm{a}}$ & $60.49 \pm 3.46^{\mathrm{ab}}$ & $62.95 \pm 8.26^{\mathrm{a}}$ & $69.03 \pm 3.81^{\mathrm{a}}$ \\
\hline Brain & $47.73 \pm 3.40^{\mathrm{a}}$ & $47.71 \pm 6.17^{\mathrm{a}}$ & $48.37 \pm 5.93^{\mathrm{a}}$ & $47.45 \pm 5.20^{\mathrm{a}}$ & $44.25 \pm 8.27^{a}$ & $45.95 \pm 1.98^{\mathrm{a}}$ \\
\hline Muscle & $63.28 \pm 3.81^{\mathrm{a}}$ & $54.75 \pm 7.15^{\mathrm{a}}$ & $56.75 \pm 7.82^{\mathrm{a}}$ & $57.29 \pm 5.17^{\mathrm{a}}$ & $62.64 \pm 8.97^{\mathrm{a}}$ & $63.44 \pm 7.39^{\mathrm{a}}$ \\
\hline Serum & $76.34 \pm 1.63^{\mathrm{a}}$ & $52.86 \pm 3.36^{\mathrm{b}}$ & $62.05 \pm 5.71^{c}$ & $73.02 \pm 2.99^{\mathrm{a}}$ & $64.33 \pm 3.29^{c}$ & $65.02 \pm 2.45^{c}$ \\
\hline \multicolumn{7}{|c|}{ Twenty four hours } \\
\hline Liver & $68.80 \pm 3.43^{\mathrm{a}}$ & $21.44 \pm 2.81^{\mathrm{b}}$ & $57.42 \pm 2.36^{c}$ & $68.93 \pm 3.40^{a}$ & $50.65 \pm 2.16^{d}$ & $57.26 \pm 1.87^{c}$ \\
\hline Kidney & $70.15 \pm 4.36^{\mathrm{a}}$ & $38.64 \pm 2.51^{b}$ & $74.25 \pm 4.36^{\mathrm{a}}$ & $64.50 \pm 3.35^{\mathrm{ac}}$ & $55.97 \pm 3.83^{d}$ & $65.82 \pm 2.33^{c}$ \\
\hline Heart & $68.74 \pm 1.87^{\mathrm{a}}$ & $49.04 \pm 4.74^{b}$ & $62.16 \pm 3.21^{\mathrm{ac}}$ & $58.62 \pm 2.33^{c}$ & $65.72 \pm 6.72^{\mathrm{ac}}$ & $62.99 \pm 3.64^{\mathrm{a}}$ \\
\hline Brain & $45.98 \pm 3.53^{\mathrm{a}}$ & $45.48 \pm 5.15^{\mathrm{a}}$ & $45.41 \pm 5.29^{\mathrm{a}}$ & $41.45 \pm 2.57^{\mathrm{a}}$ & $41.84 \pm 5.74^{\mathrm{a}}$ & $42.40 \pm 1.65^{\mathrm{a}}$ \\
\hline Muscle & $64.81 \pm 7.41^{\mathrm{a}}$ & $49.74 \pm 7.59^{b}$ & $50.15 \pm 6.20^{b}$ & $54.16 \pm 3.60^{b}$ & $53.35 \pm 6.18^{b}$ & $64.75 \pm 2.98^{\mathrm{a}}$ \\
\hline Serum & $73.80 \pm 3.40^{\mathrm{a}}$ & $51.38 \pm 4.16^{b}$ & $58.03 \pm 6.28^{b}$ & $70.26 \pm 1.62^{\mathrm{a}}$ & $59.93 \pm 1.86^{b}$ & $42.80 \pm 2.58^{c}$ \\
\hline \multicolumn{7}{|c|}{ Forty eight hours } \\
\hline Liver & $68.46 \pm 3.28^{a}$ & $19.50 \pm 1.91^{b}$ & $52.00 \pm 3.65^{c}$ & $57.50 \pm 3.41^{c}$ & $49.00 \pm 3.42^{c}$ & $53.50 \pm 2.58^{c}$ \\
\hline Kidney & $67.00 \pm 2.58^{\mathrm{a}}$ & $35.00 \pm 4.16^{b}$ & $50.24 \pm 3.65^{\mathrm{cd}}$ & $57.08 \pm 2.58^{c}$ & $58.75 \pm 4.57^{c}$ & $46.64 \pm 3.65^{d}$ \\
\hline Heart & $66.54 \pm 4.43^{\mathrm{a}}$ & $46.04 \pm 3.65^{b}$ & $50.35 \pm 0.365^{b c}$ & $53.50 \pm 3.41^{b c}$ & $56.48 \pm 1.63^{c}$ & $60.28 \pm 4.32^{\mathrm{ac}}$ \\
\hline Brain & $45.55 \pm 5.00^{\mathrm{a}}$ & $43.25 \pm 4.11^{\mathrm{a}}$ & $45.50 \pm 5.51^{\mathrm{a}}$ & $40.51 \pm 2.51^{\mathrm{a}}$ & $39.35 \pm 2.58^{a}$ & $42.25 \pm 3.09^{\mathrm{a}}$ \\
\hline Muscle & $63.62 \pm 2.61^{a}$ & $52.64 \pm 7.52^{b}$ & $67.57 \pm 3.56^{a}$ & $56.83 \pm 7.34^{\mathrm{ab}}$ & $54.26 \pm 3.68^{a b}$ & $62.02 \pm 4.40^{\mathrm{ab}}$ \\
\hline Serum & $68.50 \pm 3.41^{\mathrm{a}}$ & $45.48 \pm 3.45^{b}$ & $54.06 \pm 4.32^{b c}$ & $63.50 \pm 3.42^{\mathrm{a}}$ & $57.08 \pm 2.58^{c}$ & $48.50 \pm 6.19^{b c}$ \\
\hline
\end{tabular}

All values are expressed as Mean $\pm \mathrm{SD}$, values sharing different alphabet superscript on the same row showed a significant difference.

Key: $1=$ Control, $2=\mathrm{CdCl}_{2} 3=\mathrm{CF}+\mathrm{CdCl}_{2}, 4=\mathrm{GF}+\mathrm{CdCl}_{2}, 5=\mathrm{BF}+\mathrm{CdCl}_{2}, 6=\mathrm{UF}+\mathrm{CdCl}_{2}$

Bernhoft (2013) submits that cadmium affects the cardiovascular system in several ways especially relative to available epidemiological evidences that links $\mathrm{Cd}$ with sudden cardiac death, peripheral arterial disease and myocardial infarction (Everette and Fristein 2008;Menke et al. 2009; Messner et al. 2008). These studies are also suggestive that the possible mechanisms for cadmium mediated membrane instability include disruption of calcium ion channels, direct vasoconstriction, hampering of nitric oxide (NO) and other vasodilators, and perhaps reduced cellular oxygen uptake. This also may explain the observed early reduction reported for antioxidants (Tables $2,3,4$ ) because of a possible hypoxic state within the tissue membrane occurring from the high dose of cadmium chloride (Woo et al. 2013; Shen et al. 2020). Hypoxic state ordinarily has been established to contribute greatly to increased generation of oxidative radicals capable of antagonising the scavenging capacities of several antioxidants (Adebambo et al. 2018). Giving an explanation to the possible involvement of the hypoxic status mediated by cadmium in our earlier report (Asagba et al. 2019), is an implicative involvement of acute cadmium administration to initiate increased disruption of erythrocytes owing to drop in blood haemoglobin and reduced red blood cells which are primary transporters of oxygen within the blood and body systems. This inference is also supported by the purported ability of cadmium to significantly affect hypoxia mediated expression of haemoglobin and erythropoietin (Dangre et al. 2010). Furthermore, we noted the gradual increase and buildup of white blood cells following cadmium intoxication may be indicative of an early induction of inflammatory responses to external immune modulators (Asagba et al. 2019).

It is imperative to note that steady elevation in stress indices evidently represented by increased MDA levels in the heart has been linked to the induction of myocardial infarction (Di Fillipo et al. 2006). Results from this study (Tables $1,2,3,4$ ) gives an insight into the possible induction of myocardial infarction in only cadmium treated rats owing to an elevated lipid disarmament and reduced levels of the antioxidant markers (GSH, CAT and SOD) by cadmium $24 \mathrm{~h}$ and $48 \mathrm{~h}$ post administration periods respectively in the heart and serum. This trend were also observed in rats treated with crude palm oil and palm oil fractions (CF, GF and UF), which 
were also slowed down implying the possible action of these extracts in controlling the Cd-induced heart disorders or myocardial infarction. This claim is justifiably supported by Bester et al. (2010) who demonstrated a reduction in the level of oxidative-modified proteins as well as an attenuation of the increase in free oxygen radicals in the heart. Likewise, the study of Narang et al. (2004) used an isolated heart model of rats to demonstrate the effect of palm olein in the diet on ischemia reperfusion injury (IRI), thus the study was able to demonstrate that $5 \%$ olein-supplementation of diet, was able to increase the level of antioxidants in the myocardium but the levels of thiobabituric acid and reactive substances (TBARS) did not change and remained significant comparatively with control rats which had oxidative injury with no corresponding rise in tissue defensive enablers.

Also supporting the claim for the efficacy of palm oil and palm oil fractions to modulate the induction of myocardial infarction are evidences from literature (Esterhuyse et al. 2005a, b, 2006; Kruger et al. 2007; van Rooyen et al. 2008) supporting beneficial roles of palm oil supplemented diets against heart disease, tissue injury and myocardial infarction. In granting credence to our earlier claims, increased depletion of hepatic and renal GSH, CAT and SOD comparative to control group (Tables 2, 3, 4) in all post cadmium administration periods is in tandem with reported rise in MDA values (Table 1) relative to control. This is supported by earlier study of Asagba and Eriyamremu (2007) on a positively correlated rise in MDA values and concurrent drop in SOD, catalase, ATPase activities following oral cadmium consumption.

\section{Conclusions}

The initiation of stress markers in acute cadmium poisoning remains a significant mechanism for monitoring its negative impacts. However, the control of lipid peroxidation and allied stress indices within the membrane architecture in the different tissues is a justifiable mechanism for the conferment of the protective roles of palm oil fractions against acute cadmium induced toxicity. These observations therefore may be a scientific based justification for the increased advocacy for incorporation of red palm oil into several of our diets as it has the tendency to boost and elicit the body's antioxidant defence system.

\footnotetext{
Abbreviations

CF: Crude Palm Oil Fraction; UF: Unsaponifiable Palm Oil Fraction; GF: Silica Gel Fraction; BF: Bleached Palm Oil Fraction; TBARS: Thiobarbitoric Acid Reactive Substance; MDA: Malondialdehyde; PUFA: Polyunsaturated Fatty Acid; GSH: Reduced Glutathione; SOD: Superoxide Dismutase; CAT: Catalase; ANOVA: Analysis of Variance.
}

Authors' contributions

Conception and Supervision: SOA and CN; Data Gathering: PCI, CN and JCM, Data Analysis: PCI, JCO and JCM, Initial Draft and Literature Review: PCI, JCO and CN, Final Draft/Review: PCI, CN, JCM, JCO and SOA. All authors read and approved the final manuscript.

\section{Funding}

This study did not receive any form of sponsorship or external funding.

\section{Availability of data and materials}

All data used for this study are available and have been included in the manuscript.

\section{Declarations}

\section{Ethics approval and consent to participate}

Approval for the current study was given by the Faculty of Science Ethics committee and it has an approved study number ETH/15/16/PG223056. The ethics for the study also conformed to the guidelines for animal research stated by the Animal Research Ethics (2009) and the World Medical Association (2016) on use of animal for research.

\section{Consent for publication}

Not applicable.

\section{Competing interests}

Authors have no competing interest to declare.

\section{Author details}

${ }^{1}$ Department of Biochemistry, Faculty of Science, Delta State University, Abraka, Nigeria. ${ }^{2}$ Department of Medical Biochemistry, Faculty of Basic Medical Sciences, Delta State University, Abraka, Nigeria. ${ }^{3}$ Department of Human Anatomy, Faculty of Basic Medical Sciences, Novena University, Ogume, Nigeria. ${ }^{4}$ Present Address: Department of Psychology, Faculty of Health Sciences, The Arctic University of Norway, Tromsø, Norway.

Received: 12 October 2021 Accepted: 16 December 2021

Published online: 04 January 2022

\section{References}

Achuba FI (2018) Modulation of crude oil induced alteration of oxidative stress indices in rat by red palm oil. J Appl Sci Environ Manag 22(6):929-932. https://doi.org/10.4314/jasem.v22i6.15

Achuba Fl, Ogwumu MD (2014) Effect of palm oil and beef liver on diesel-induced haematotoxicity in wistar albino rats. Biokemistri 26(4):120-123

Adebambo OA, Shea D, Fry RC (2018) Cadmium disrupts signaling of the hypoxia-inducible (HIF) and transforming growth factor (TGF- $\beta$ ) pathways in placental JEG-3 trophoblast cells via reactive oxygen species. Toxicol Appl Pharmacol 342:108-115. https://doi.org/10.1016/j.taap.2018.01.010

Agency for Toxic Substances and Disease Registry (ATSDR) (2008) Toxicological Profile for Cadmium. Draft for public comment. US Department of Health and Human Services, Atlanta

Ahmad AL, Chan CY, Abd-Shukor SR, Mashitah MD (2008) Recovery of oil and carotenes from palm oil mill effluent (POME). Chem Eng J 141:383-386

Animal Research Ethics (2009) A handbook of USP researchers, vol 2. Research Office Publisher, South Pacific, pp 3-4

Asagba SO, Eriyamremu GE (2007) Oral cadmium exposure and levels of superoxide dismutase, catalase, lipid peroxidation and ATPases in the eye. Res J Environ Toxicol 1(4):204-209

Asagba SO, Obi FO (2005) A comparative evaluation of the biological effects of environmental cadmium contaminated control diet and laboratory cadmium supplemented test diets. Biometal 2005(18):155-161

Asagba SO, Ichipi-Ifukor PC, Ichipi-Ifukor RN, Oyem JC (2019) Palm oil fractions alter acute cadmium mediated haematotoxicity. Galician Med J 26(3):E201933 
Atagana OS, Asagba SO (2015) Protective effects of honey against cadmium induced alteration of some biochemical parameters in rats. Toxicol Environ Chem. https://doi.org/10.1080/02772248.1027205

Bernhoft RA (2013) Cadmium toxicity and treatment. Sci W J 39:4652

Bester D, Esterhuyse A, Truter E, Van Rooyen J (2010) Cardiovascular effects of edible oils: a comparison between four popular edible oils. Nutr Res Rev 23(2):334-348. https://doi.org/10.1017/S0954422410000223

Chandrasekharan N, Sundram K, Basiron Y (2000) Changing nutritional and health perspectives on palm oil. Brunei Intl Med J 2:417-427

Cohen HJ, Betcher-Lange S, Kessler DL, Rajagopalan KV (1972) Hepatic sulphite oxidase congruency in mitochondria of prosthetic groups and activity. J Biol Chem 247(2):7759-7766

Dangre AJ, Manning S, Brouwer M (2010) Effects of cadmium on hypoxiainduced expression of hemoglobin and erythropoietin in larval sheepshead minnow. Cyprinodon Variegatus Aquatic Toxicol 99(2):168-175. https://doi.org/10.1016/j.aquatox.2010.04.015

Di Filippo C, Cuzzocrea S, Rossi F, Marfella R, D’Amico M (2006) Oxidative stress as the leading cause of acute myocardial infarction in diabetics. Cardiovasc Drug Rev 24(2):77-87

Dong Q, Fei L, Wang C, Hu S, Wang Z (2019) Cadmium excretion via leaf hydathodes in tall fescue and its phytoremediation potential. Environ Pollut 252:1406-1411

Edem DO (2002) Palm oil: Biochemical, physiological, nutritional, hematological and toxicological aspects: a review. Plant Foods Hum Nutr 57:319-341

Edem DO, Akpanabiatu MI (2006) Effects of palm oil-containing diets on enzyme activities of rats. Pak J Nutr 5:301-305

Ekwenye UN, ljeomah CA (2005) Antimicrobial effects of palm kernel oil and palm oil. KMITL Sci J 5:502-505

Ellman GC (1959) Tissue sulflydryl groups. Arch Biochem Biophys 82:70-77

Esterhuyse AJ, du Toit EF, Benadè AJ, van Rooyen J (2005a) Dietary red palm oil improves reperfusion cardiac function in the isolated perfused rat heart of animals fed a high cholesterol diet. Prostagl Leukot Essent Fatty Acids 72:153-161

Esterhuyse AJ, du Toit EF, van Rooyen J (2005b) Dietary red palm oil supplementation protects against the consequences of global ischemia in the isolated perfused rat heart. Asian Paci J Clin Nutr 14(4):340-347

Esterhuyse AJ, van Rooyen J, Strijdom H, Bester D, du Toit EF (2006) Proposed mechanisms for red palm oil induced cardio-protection in a model of hyperlipidaemia in the rat. Prostagl Leukotessent Fatty Acids 75:375-384

EverettCJ FIL (2008) Association of urinary cadmium and myocardial infarction. Environ Res 106(2):284-286

Gutbrod P, Reichert S, Gutbrod K, Hamai A, Bréhélin C, Ngando-Ebongue G, Dörmann P (2021) Fatty acid isoprenoid alcohol ester synthesis in fruits of the African oil palm (Elaeis guineensis). Phytochemistry 185:112684

Gutteridge JMC, Wilkins C (1982) Copper dependent hydroxyl radical damage to ascorbic acid. Formation of a thiobarbiturie acid reactive products. Febsletter 137:327-340

Ichipi-Ifukor PC, Evwhre OL, Eferobohwo A (2013) A comparative study of the effect of cadmium and arsenic On the Activities of brain sulphite oxidase and aldehyde oxidase in the african cat fish (Clariasgariepienus). J Res Biosci 9(1):68-71

Ichipi-Ifukor PC, Asagba SO, Kweki GR, Nwose C (2019b) Attenuation of oxidative enzymes induction in Palm Oil Fractions Pre-treated Cadmium intoxicated rats. Trop J Nat Prod Res 3(4):107-112

Ichipi-Ifukor PC, Asagba SO, Nwose C (2019a) Potentiating role of palm oil (Elaeisguineensis) and its extracts in cadmium-induced alteration of amino transferases. Thai J Pharm Sci 43(1):38-46

InabaT KE, Suwazono Y, Uetani M, Oishi M, Nakagawa H (2005) Estimation of cumulative cadmium intake causing Itai-Itaidisease. Toxicol Lett 159(2):192-201

Isamah GK, Asagba SO (2004) A comparative study on the archives of xanthine oxidase and aldehyde oxidase in different fish species from two rivers in the Western Niger-Delta. Environ Monit Assess 91:293-300. https://doi. org/10.1023/B:EMAS.0000009242.94035.a4

Ismail SR, Maarof SK, Siedar Ali S, Ali A (2018) Systematic review of palm oil consumption and the risk of cardiovascular disease. Plos One 13(2):e0193533. https://doi.org/10.1371/journal.pone.0193533

Jager R, Purpura M, Kingsley M (2007) Phospholipids and sports performance. J Int Soc Sports Nutr 4:1-8
Johnson W, Slag TJ (2009) Final report on the safety assessment of Elaeisguineensis (Palm) Oil, Elaeisguineensis (Palm) Kernel Oil, hydrogenated Palm Oil and hydrogenated Palm Kernel Oil. Int J Toxicol 19:7-28

Karl-Heinz S, Magnus P (2000) Cadmium and cadmium compounds. IARC Monogr Eval Carcinog Risks Hum 58:1 19-237

Kruger MJ, Engelbrecht AM, Esterhuyse J, du Toit EV, van Rooyen J (2007) Dietary red palm oil reduces ischaemia-reperfusion injury in rats fed a hypercholesterolaemic diet. Br J Nutr 97:653-660

Kweki GR, Ichipi-Ifukor PC, Asagba SO (2018) High caffeine-containing energy drink-induced metabolic stress in rats. SJMLS 3(3):86-93

Lara Alvarenga G, Sarria Cuevas M, Carolina Capellini M, José Crevellin E, Alberto Beraldo de Moraes L, Elisabete da Costa Rodrigues C (2019) Extraction of carotenoid-rich palm pressed fiber oil using mixtures of hydrocarbons and short chain alcohols. Food Res Int 128:108810

Liu J, Simon LM, Phillips JR, Robin ED (1977) Superoxide dismutase (SOD) activity in hypoxic mammalian systems. J Appl Physiol Respir Environ Exerc Physiol 42(1):107-110. https://doi.org/10.1152/jappl.1977.42.1.107

Mahlia TMI, Ismail N, Hossain N, Silitonga AS, Shamsuddin AH (2019) Palm oil and its wastes as bioenergy sources: a comprehensive review. Environ Sci Pollut Res. https://doi.org/10.1007/s11356-019-04563-x

Massányi P, Massányi M, Madeddu R, Stawarz R, Lukáć N (2020) Effects of cadmium, lead and mercury on the structure and function of reproductive organs. Toxics 8(4):94

Meloan CE (2009) Chemical separations: principles, techniques and experiments. Wiley, New York, pp 23-34

Menke A, Muntner P, Silbergeld EK, Platz EA, Guallar E (2009) Cadmium levels in urine and mortality among US adults. Environ Health Perspect 117(2):190-196

Messner B, Knoflach M, Seubert A (2008) Cadmium is a novel and independent risk factor for early atherosclerosis mechanisms and in vivo relevance. Arterioscler Thromb Vasc Bio 29(9):1392-1398

Misra HP, Fridovich I (1972) The Role of Superoxide ion in the auto-oxidation of epinephrine and a simple assay for superoxide dismutase. J Biol Chem 1972(247):3170-3175

Narang D, Sood S, Thomas MK, Dinda AK, Maulik SK (2004) Effect of dietary palm olein oil on oxidative stress associated with ischemic-reperfusion injury in isolated rat heart. BMC Pharmacol 4:29

Nguefack F, Chiabi A, Ndounia SN, Bogne JB, Mah E, Nguefack S, Fru All (2017) Clinical and epidemiologic study on unintentional domestic poisoning at the paediatric service of the Yaounde Gynaeco-Obstetric and Pediatric Hospital. J Med Res 3(3):164-168

Nwokocha CR, Owu DU, Ufearo CS, I wuala MO (2011) Comparative study on the efficacy of Garcinia kola in reducing some heavy metal accumulation in liver of Wistar rats. J Ethnopharm 135:488-491

Nwokocha CR, Nwokocha MI, Owu DU, Obi J, Olatunde B, Ebe C, Nwangwu O, Iwuala MO (2012) Comparative analysis on the effect of palm oil (Elaeisguineensis) in reducing cadmium and lead accumulation in liver of Wistar rats. Pharmacognosy 4(4):214-218

Obahiagbon FI (2012) A review: aspects of the African oil palm (Elaeisguineesisjacq.) and the implications of its bioactives in human health. Am J Biochem Mol Biol 2:106-119

Oguntibeju OO, Esterhuyse AJ, Truter EJ (2012) Red palm oil and its antioxidant potential in reducing oxidative stress in HIV/AIDS and TB patients. In: Dhanjoo NG (ed) Biomedical science, engineering and technology, IntechOpen. http://www.intechopen.com/books/biomedical-scienceengineering-and-echnology/red-palm-oil-and-itsantioxidant

Okpoghono J, Achuba Fl, George BO (2018) Protective effect of Monodora myristica extracts on crude petroleum oil contaminated catfish (Clarias gariepinus) diet in rats. Intl J Vet Sci Med 6(1):117-122

Ononogbu IC (1990) Cassava processing and cyanide poisoning. Paper presented at the 2 nd African conference on the biochemistry of Lipids, University of Nigeria, Enugu Campus, 6-10 November

Orororo OC, Asagba SO, Tonukari NJ, Okandeji OJ, Mbanugo JJ (2018a) Hibiscus Sabdarrifa L. Anthocyanins-induced changes in reproductive hormones of cadmium-exposed rats. Int J Sci Res Publ 8(4):308-311

Orororo OC, Asagba SO, Tonukari NJ, Okandeji OJ, Mbanugo JJ (2018b) Comparative assessment of the antioxidant properties of Hibiscus sabdarrifa $L$ anthocyanins and its aqueous extract in cadmium-exposed rats. Res J Pharmacol Bio Chem Sci 9(3):836-843 
Orororo OC, Asagba SO, Oliseneku EO, E, (2018c) Effect of garden egg, carrot and oat-supplements on biochemical parameters in cadmium exposed rats. Afr J Biochem Res 12(3):28-34

Orororo OC, Asagba SO, Tonukari NJ, Okandeji OJ, Mbanugo JJ (2018d) Cadmium-induced testicular damage in wistar rats: protective effects of Hibicus sabdarrifa L anthocyanin. Int J Biochem Res Rev 21(4):1-8

Orororo OC, Asagba SO, Tonukari NJ, Okandeji OJ, Mbanugo JJ (2018e) Effects of Hibiscus Sabdarrifa L anthocyanins on cadmium-induced oxidative stress in Wistar rats. JASEM 22(4):465-470

Osei EY (2013) Treatment of lead-poisoned rats through oral administration of palm oil extracts. M.Phil. thesis, Kwame Nkrumah University of Science and Technology

Owoyele BV, Owolabi GO (2014) Traditional oil palm (Elaeis guineensis jacq.) and its medicinal uses: a review. Tang Hum Med 4(3):e16. https://doi.org/ 10.5667/tang.2014.0004

Oyem JC, Chris-Ozoko LE, Enaohwo MT, Otabor FO, Okudayo VA, Udi OA (2021) Antioxidative properties of Ocimum gratissimum alters Lead acetate induced oxidative damage in lymphoid tissues and hematological parameters of adult Wistar rats. Tox Rep 8:215-222

Patterson HWB (1992) Bleaching and purifying fats and oils. Theory and practice. AOCS Press, Kualar Lumpur, pp 45-65

Ramalingam M, Kim S (2012) Reactive oxygen/nitrogen species and their func tional correlations in neurodegenerative diseases. J Neurosci Transmision 2012(119):87

Sasidharan S, Selvarasoo L, Latha Y (2012) Wound healing activity of Elaeis guineensis leaf extract ointment. Intl J Mol Sci 13:336-347

Shen WT, Huang YJ, Zhang Q, Lin F, Wang X, Ye DY, Huang YP (2020) SCH58261, the antagonist of adenosine A2A receptor, alleviates cadmium-induced preeclampsia via sirtiun-1/hypoxia-inducible factor-1a pathway in rats. Eur Rev Med Pharmacol Sci 24(21):10941-10953

Starks MA, Starks SL, Kingsley M, Purpura M, Jager R (2008) The effects of phosphatidylserine on endocrine response to moderate intensity exercise. J Intl Soc Sports Nutr. https://doi.org/10.1186/1550-2783-5-11

Sundram K (2011) Modulation of human lipids and lipoproteins by dietary palm oil and palm olein: a review. Asia Pac J Clin Nutr 6(1):12-16

Twumasi P, Nsiah K, Osei EY (2014) Treatment of lead-poisoned rats through oral administration of palm oil extracts. Afr J Biochem Res 8(2):43-51

Uvere PO (1999) Reactivity of red palm oil and cyanide ion: implications for the cyanogen content of palm oil-treated garri. Plant Foods Hum Nutr 53:249-253

van Rooyen J, Esterhuyse AJ, Engelbrecht A, du Toit EF (2008) Health benefits of natural carotenoid rich oil: a proposed mechanism of protection against ischaemia reperfusion injury. Asia Pac J Clin Nutr 17:316-319

Woo S, Denis V, Won H, Shin K, Lee G, Lee T, Yum S (2013) Expressions of oxidative stress-related genes and antioxidant enzyme activities in Mytilus galloprovincialis (Bivalvia, Mollusca) exposed to hypoxia. Zool Stud 2013(52):15. https://doi.org/10.1186/1810-522X-52-15

World Medical Association (2016) WMA statement on animal use in biomedical research

Zeisel SH, Char D, Sheard NF (1986) Choline, phosphatidylcholine and sphingomyelin in human and bovine milk and infant formulas. J Nutr 116:50-58

\section{Publisher's Note}

Springer Nature remains neutral with regard to jurisdictional claims in published maps and institutional affiliations.

\section{Submit your manuscript to a SpringerOpen ${ }^{\circ}$ journal and benefit from:}

- Convenient online submission

- Rigorous peer review

- Open access: articles freely available online

- High visibility within the field

- Retaining the copyright to your article

Submit your next manuscript at $\boldsymbol{\nabla}$ springeropen.com 